Vermicompost Leachate Reduces \title{
Temperature and Water Stress Effects in Tomato Seedlings
}

\author{
Mayashree Chinsamy, Manoj G. Kulkarni, and Johannes Van Staden'1 \\ Research Centre for Plant Growth and Development, School of Life Sciences, \\ University of KwaZulu-Natal Pietermaritzburg, Scottsville, South Africa
}

Additional index words. abiotic stresses, chlorophyll, organic liquid, proline, sugars, tomato

\begin{abstract}
Abiotic stresses negatively affect the rate of nutrient mobilization in soils resulting in poor crop performance. Vermicompost-leachate (VCL) is an organic liquid produced from earthworm-digested material. It improves soil fertility as a result of the presence of proteins, vitamins, and micro- and macroelements. However, the effects of VCL on plant growth under temperature and water stress are not yet fully studied. To assess the growth performance under low, optimum, and high temperatures, 1-monthold well established tomato seedlings were treated with and without VCL $(1: 10 \mathrm{v} / \mathrm{v})$ under various temperature regimes $\left(10,15,20,25\right.$, and $\left.30{ }^{\circ} \mathrm{C}\right)$. In the second trial, tomato seedlings were tested in a greenhouse with and without VCL $(1: 10 \mathrm{v} / \mathrm{v})$ at different watering regimes $(15,30$, and $45 \mathrm{~mL}$ of Hoagland's nutrient solution) to evaluate the effect of water stress. In comparison with the control seedlings, VCL treatment significantly improved stem thickness, leaf area, and shoot/root both fresh and dry weight of seedlings at $30{ }^{\circ} \mathrm{C}$. At this temperature, VCL-treated seedlings showed a significant increase for all examined physiological parameters (total chlorophyll, total sugars, and proline). Number of leaves, stem thickness, and shoot/root length and fresh weight of VCL-treated tomato seedlings irrigated under a low watering regime were significantly greater than the control. Total chlorophyll, total sugars, and proline content were significantly elevated at the high watering regime but declined in the low watering regime with VCL treatment. Both increasing and decreasing trends of compatible solutes and photosynthetic pigments indicated osmotic adjustment to stress conditions. VCL can be a suitable soil amendment product to improve overall soil fertility and, more importantly, growth of tomato plants even under temperature and water stress conditions.
\end{abstract}

Tomatoes originated from the warmer subtropical Andean region, and according to Criddle et al. (1997), almost no growth is expected below $12{ }^{\circ} \mathrm{C}$. Prolonged cold periods cause chilling injuries attributed to altered biochemical and photosynthetic pathways, respiration, and water relations. Elevated temperatures reduce shoot weight, induce accumulation of phenolics, and affect certain physiological processes in tomato plants (Abdelmageed et al., 2003; Rivero et al., 2001). Water-stressed tomato plants have a significantly reduced nitrogen, sodium, potassium, sulfur, calcium, and magnesium content (Nahar and Gretzmacher, 2002). Water stress applied at different growth stages affected tomato fruit yield and quality (Nuruddin et al., 2003).

Abiotic plant stresses such as drought, extreme temperature, and saline conditions negatively affect tomato productivity as

Received for publication 13 June 2014. Accepted for publication 14 July 2014.

The University of KwaZulu-Natal Pietermaritzburg, South Africa, provided financial support. We thank Mrs. Alison Young (University of KwaZulu-Natal, Botanical Garden, Pietermaritzburg) and her staff for technical assistance during the greenhouse experiment.

${ }^{1}$ To whom reprint requests should be addressed; e-mail rcpgd@ukzn.ac.za. a result of reduced growth, yield, and thus economic returns. These natural processes reduce the nutrient content and lifespan of the soils that translates to certain fertility constraints (Sanchez et al., 1982). According to the soil fertility capability classification, fertility constraints such as low cation exchange capacity (CEC) of soils is characterized by low organic matter content and low nutrient retention capacity, which can impose stress on a plant. Low CEC soils are generally found in arid and semiarid regions.

Use of synthetic fertilizers to improve the nutrient quality and organic content of low CEC soils and soils experiencing climatic constraints is not a sustainable measure. However, soil organic matter can be considerably improved by using alternative soil ameliorants such as VCL, which is an organic liquid produced from earthworm-digested material and casts during the vermicomposting process. Earthworm casts present in vermicompost contain proteins, vitamins, and micro- and macroelements such as nitrogen, phosphorous, potassium, calcium, and magnesium as available resources (Sinha et al., 2009). Vermicompost-leachate increases beneficial microbial populations, thereby improving soil fertility, which essentially improves agronomic and horticultural crop performance (Chaoui et al., 2003). When compared with conventional compost applications, treatment with earthworm casts was far better in reducing plant stress (Chaoui et al., 2003). Arthur et al. (2012) reported on the beneficial effects of VCL under deficiency of macroelements on tomato seedlings. There are no reports thus far on the effects of VCL on tomato seedlings under temperature and water stress, which are two of the major factors affecting tomato seedlings during growth and transplanting. This study evaluated the potential of VCL to enhance the growth of tomato seedlings under temperature and water stress conditions.

\section{Materials and Methods}

Plant material. Commercial tomato ( $\mathrm{Lyco}$ persicon esculentum Mill var. Heinz-1370) seeds were purchased from McDonald Seeds, Pietermaritzburg, South Africa. Seeds were stored in the dark at $10^{\circ} \mathrm{C}$ until use.

Vermicompost-leachate solution. Vermicompost-leachate derived from garden waste using red earthworms Eisenia fetida was purchased from WizzardWorms, Rietvlei, KwaZulu-Natal, South Africa. The average $\mathrm{pH}$ (7.82) and nutrient content of the VCL on a dry matter basis (nitrogen 2.26\%; phosphorus $0.99 \%$; potassium $0.64 \%$; calcium $2.52 \%$; and sodium $631.03 \mathrm{mg} \cdot \mathrm{kg}^{-1}$ ) was provided by the manufacturer. VCL dilution of $1: 10(\mathrm{v} / \mathrm{v})$ was prepared with Hoagland's half-strength nutrient solution $(50 \%)$ (Hoagland and Snyder, 1933) and was used as a test solution.

Growing medium. Perlite as a propagating and growing medium has shown better performance over soil. Recently the use of perlite has become very popular in horticultural applications. To maintain control and uniform soil/substrate conditions, perlite as a substrate and Hoagland's solution as a nutrient were used in this study to evaluate the effect of VCL on tomato seedlings under temperature and water stress conditions.

Temperature stress. Three tomato seeds were sown in a $100-\mathrm{mL}$ pot at a depth of $1 \mathrm{~cm}$ in perlite on 18 June 2012. These pots were placed in a growth chamber (Conviron; Controlled Environments Ltd., Winnipeg, Canada) at $25{ }^{\circ} \mathrm{C}$ under 16:8-h light:dark conditions. The perlite was wetted with $50 \mathrm{~mL}$ Hoagland's half-strength nutrient solution (50\%) every second day for 1 month. On 8 July 2012, two seedlings were uprooted leaving a single seedling in each pot. Pots with established tomato seedlings were then placed at $10,15,20,25$, and $30^{\circ} \mathrm{C}$ and were treated with and without VCL $(1: 10 \mathrm{v} / \mathrm{v})$ on 16 July 2012 . The experiment was conducted in controlled-temperature chambers (Conviron; Controlled Environments Ltd.) at 16:8 h light: dark with an average photosynthetic photon flux $(P P F)$ density of $85 \mu \mathrm{mol} \cdot \mathrm{m}^{-2} \cdot \mathrm{s}^{-1}$. Pots were irrigated once a week with control (Hoagland's nutrient solution) and test solutions $(50 \mathrm{~mL})$ for the first 4 weeks after the initiation of treatment. Thereafter, seedlings were treated twice weekly until termination of the experiment on 27 Aug. 2012. The added quantity of the test solution or control for 10,15 , and $20^{\circ} \mathrm{C}$ was $30 \mathrm{~mL}$ each and 
$50 \mathrm{~mL}$ for 25 and $30^{\circ} \mathrm{C}$ each. The experiment had four replicates of five pots each (20 pots in total). Each pot consisted of a single tomato seedling. Morphological data of 20 plants, which included length and weight of shoot/root, stem thickness, number of leaves, and plant leaf area, were measured on 27 Aug. 2012 (10-week-old seedlings). Stem thickness and plant leaf area (without separating leaves) were measured using a vernier caliper and a leaf area meter (LI-3100; LI-COR Inc., Lincoln, NE), respectively. Subsequently, plant material was oven-dried at $70 \pm 2{ }^{\circ} \mathrm{C}$ for $72 \mathrm{~h}$ to determine dry weight.

Watering stress. The procedure of raising seedlings and period was similar to the temperature stress experiment. The only difference was that these seedlings were grown under greenhouse conditions with $60 \% \pm 5 \%$ relative humidity at $22 / 15{ }^{\circ} \mathrm{C}$ day/night temperatures and an average $P P F$ density of $450 \mu \mathrm{mol} \cdot \mathrm{m}^{-2} \cdot \mathrm{s}^{-1}$ (11-h daylength). On 16 July 2012, established tomato seedlings were treated with and without VCL $(1: 10 \mathrm{v} / \mathrm{v})$ at varying volumes $(15,30$, and $45 \mathrm{~mL})$ of Hoagland's half-strength nutrient solution $(50 \%)$. VCL $1: 10 \mathrm{v} / \mathrm{v}$ was made up with Hoagland's half-strength nutrient solution $(50 \%)$. After initiation of treatment, tomato seedlings were treated once a week for the first 4 weeks. Thereafter, seedlings were treated twice weekly until termination of the experiment on 27 Aug. 2012. The experiment had four replicates of five pots each (20 pots in total). The growth parameters were measured on 27 Aug. 2012 (10-week-old seedlings) as described in the temperature stress experiment.

Physiological parameters. Photosynthetic pigment (chlorophyll a, b, and total chlorophyll) content was extracted by homogenizing fresh leaf samples $(5 \mathrm{~g})$ of treated and control seedlings in $80 \%$ acetone $(20 \mathrm{~mL})$ using a homogenizer. The resultant solution was filtered through Whatman No. 1 filter paper using $80 \%$ acetone $(10 \mathrm{~mL})$ to rinse the residue on the filter paper. The volume of filtrate was adjusted to $50 \mathrm{~mL}$ using $80 \%$ acetone and the optical density measured at 645 and $663 \mathrm{~nm}$ with spectrophotometer (Varian Cary 50, Mulgrave, Australia). The chlorophyll pigment content ( $\mathrm{mg} \cdot \mathrm{g}^{-1}$ tissue) was estimated using the following formulae:

$$
\begin{aligned}
& \text { Chlorophyll a }\left(\mathrm{C}_{\mathrm{a}}\right)=\left[12.7\left(\mathrm{~A}_{663}\right)-2.69\right. \\
& \left.\left(\mathrm{A}_{645}\right)\right] \times \mathrm{Vol} \times(0.001) \times \mathrm{W} \\
& \text { Chlorophyll b }\left(\mathrm{C}_{\mathrm{b}}\right)=\left[22.9\left(\mathrm{~A}_{645}\right)-4.68\right. \\
& \left.\left(\mathrm{A}_{663}\right)\right] \times \mathrm{Vol} \times(0.001) \times \mathrm{W} \\
& \text { Total chlorophyll }=\left[20.2\left(\mathrm{~A}_{645}\right)+8.02\right. \\
& \left.\left(\mathrm{A}_{663}\right)\right] \times \mathrm{Vol} \times(0.001) \times \mathrm{W}
\end{aligned}
$$

where A is the absorbance, Vol is the total volume of filtrate, and $\mathrm{W}$ is the weight of the leaf material.

The proline content was determined with the sulfosalicylic acid method (Bates et al., 1973). Fresh leaf samples (0.4 g) were homogenized with $3 \%$ sulfosalicylic acid $(5 \mathrm{~mL})$ and boiled for $10 \mathrm{~min}$. An aliquot of the resultant supernatant $(2 \mathrm{~mL})$ together

Table 1. Effect of vermicompost-leachate $(1: 10 \mathrm{v} / \mathrm{v})$ on morphological growth parameters of tomato seedlings (10-week-old) under different temperature regimes $(\mathrm{n}=5) .^{\mathrm{z}}$

\begin{tabular}{cccc}
\hline Treatment & Leaf number & Stem thickness $(\mathrm{mm})$ & Plant leaf area $\left(\mathrm{cm}^{2}\right)$ \\
\hline Untreated & & & \\
$10^{\circ} \mathrm{C}$ & $4.7 \pm 0.1 \mathrm{c}$ & $2.4 \pm 0.14 \mathrm{~d}$ & $39 \pm 3.5 \mathrm{c}$ \\
$15^{\circ} \mathrm{C}$ & $5.0 \pm 0.2 \mathrm{bc}$ & $3.3 \pm 0.15 \mathrm{c}$ & $48 \pm 4.1 \mathrm{c}$ \\
$20^{\circ} \mathrm{C}$ & $5.9 \pm 0.3 \mathrm{~b}$ & $3.3 \pm 0.09 \mathrm{c}$ & $56 \pm 5.9 \mathrm{c}$ \\
$25^{\circ} \mathrm{C}$ & $6.8 \pm 0.2 \mathrm{a}$ & $3.7 \pm 0.10 \mathrm{~b}$ & $128 \pm 12.7 \mathrm{a}$ \\
$30^{\circ} \mathrm{C}$ & $6.6 \pm 0.2 \mathrm{a}$ & $3.3 \pm 0.09 \mathrm{c}$ & $65 \pm 8.5 \mathrm{c}$ \\
$\mathrm{VCL}-$ treated $(1: 10 \mathrm{v} / \mathrm{v})$ & & & \\
$10^{\circ} \mathrm{C}$ & $5.3 \pm 0.1 \mathrm{bc}$ & $3.3 \pm 0.15 \mathrm{c}$ & $52 \pm 3.4 \mathrm{c}$ \\
$15^{\circ} \mathrm{C}$ & $5.7 \pm 0.1 \mathrm{~b}$ & $3.3 \pm 0.16 \mathrm{c}$ & $59 \pm 3.8 \mathrm{c}$ \\
$20^{\circ} \mathrm{C}$ & $5.2 \pm 0.1 \mathrm{bc}$ & $3.1 \pm 0.05 \mathrm{c}$ & $60 \pm 3.8 \mathrm{c}$ \\
$25^{\circ} \mathrm{C}$ & $6.4 \pm 0.3 \mathrm{a}$ & $4.0 \pm 0.15 \mathrm{a}$ & $128 \pm 17.4 \mathrm{a}$ \\
$30^{\circ} \mathrm{C}$ & $7.0 \pm 0.3 \mathrm{a}$ & $3.8 \pm 0.12 \mathrm{ab}$ & $101 \pm 10.1 \mathrm{~b}$ \\
$F$-value & 14.73 & 14.51 & 14.90 \\
$P$ value & $<0.001$ & $<0.001$ & $<0.001$ \\
\hline
\end{tabular}

${ }^{\mathrm{z}}$ Mean values $( \pm \mathrm{SE})$ in each column with different letters are significantly different according to Duncan's multiple range test $(P<0.05)$.

$\mathrm{VCL}=$ vermicompost-leachate.
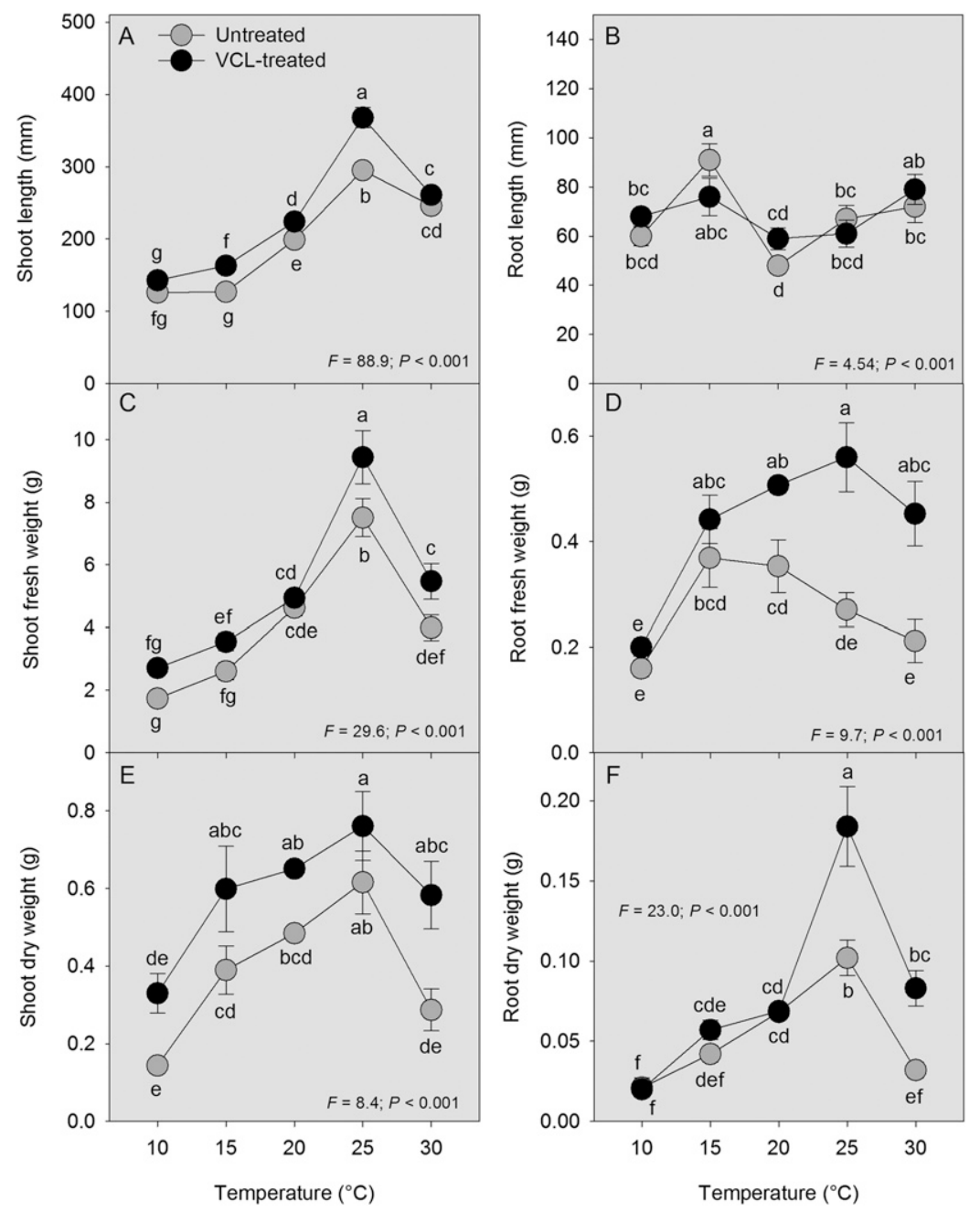

Fig. 1. (A-F) Effect of vermicompost-leachate $(1: 10 \mathrm{v} / \mathrm{v})$ on shoot and root growth parameters of tomato seedlings $(10$-week-old) grown under different temperature regimes $(n=5)$. Symbols $( \pm S E)$ with different letters are significantly different according to Duncan's multiple range test $(P<0.05)$.

with distilled water $(2 \mathrm{~mL})$, glacial acetic acid $(2 \mathrm{~mL})$, and $4 \mathrm{~mL}$ of acid-Ninhydrin (1.25 g Ninhydrin warmed in $30 \mathrm{~mL}$ glacial acetic acid and $20 \mathrm{~mL} 6 \mathrm{M}$ phosphoric acid) was boiled for $60 \mathrm{~min}$ and thereafter cooled on ice to end the reaction. Toluene
(4 $\mathrm{mL})$ was added to the cooled solution, which was vortexed and allowed to stand for $30 \mathrm{~min}$ at room temperature $\left(\approx 23{ }^{\circ} \mathrm{C}\right)$. The optical density of the upper phase was measured at $520 \mathrm{~nm}$ using $1 \mathrm{~mL}$ toluene as the blank. 
Total soluble sugar content was determined using the anthrone method, where leaf sugars were extracted with $80 \%$ ethanol $(4 \mathrm{~mL})$ at $80{ }^{\circ} \mathrm{C}$ for $40 \mathrm{~min}$ followed by centrifugation at $2000 \times g$ for $15 \mathrm{~min}$ (Men and Liu, 1995). The leaf sugar ethanol extract $(0.1 \mathrm{~mL})$ was reacted with $3 \mathrm{~mL}$ anthrone reagent $\left[0.2 \mathrm{~g}\right.$ anthrone in $100 \mathrm{~mL} \mathrm{H}_{2} \mathrm{SO}_{4}$ $(1: 0.4 \mathrm{v} / \mathrm{v})]$ in a boiling water bath for $10 \mathrm{~min}$. Total soluble sugar content was estimated by measuring the optical density of cooled samples at $625 \mathrm{~nm}$.

Statistical analysis. One-way analysis of variance using GenStat statistical package for Windows $\left(\right.$ GenStat $^{\circledR}$ 14th; VSN International, Hemel Hempstead, U.K.) was performed on all data sets. The mean values were separated using Duncan's multiple range test $(P<0.05)$, as indicated by letters.

\section{Results}

In treated and untreated tomato seedlings, more leaves developed as the temperature increased (Table 1). Stem thickness significantly increased in VCL-treated tomato seedlings at 10,25 , and $30^{\circ} \mathrm{C}$ in comparison with the respective controls (Table 1). The largest plant leaf area was recorded at the optimum temperature $\left(25^{\circ} \mathrm{C}\right)$ for the control. The most significant difference in plant leaf area was recorded at $30{ }^{\circ} \mathrm{C}$ with VCL-treated seedlings having $36 \%$ greater leaf area than the control (Table 1).

At the optimum temperature $\left(25^{\circ} \mathrm{C}\right)$, shoot length and fresh weight were significantly increased in VCL-treated seedlings when compared with the control seedlings (Figs. 1A and 1C). A similar trend was observed for root fresh and dry weight (Figs. $1 \mathrm{D}$ and $\mathrm{F}$ ). At $30^{\circ} \mathrm{C}$, fresh and dry weights of VCL-treated tomato seedling shoots (Figs. $1 \mathrm{C}$ and $1 \mathrm{E}$ ) and roots (Figs. 1D and $1 \mathrm{~F}$ ) were significantly higher than the controls. The most significant increase in chlorophyll a, b, and total chlorophyll in VCL-treated tomato seedlings was recorded at $30^{\circ} \mathrm{C}$ (Fig. 2A-C) compared with the respective control. This temperature $\left(30^{\circ} \mathrm{C}\right)$ also showed significant increase in total soluble sugars (Fig. 2D). Vermicompost-leachate-treated seedlings accumulated significantly higher amounts of proline at $10,20,25$, and $30^{\circ} \mathrm{C}$ (Fig. 2E). At $15^{\circ} \mathrm{C}$ there was a nonsignificant increase in proline content.

Total number of leaves, plant leaf area, and stem thickness of VCL-treated seedlings supplied with $30 \mathrm{~mL}$ Hoagland's nutrient solution were significantly higher than the respective controls (Table 2). At a low watering regime $(15 \mathrm{~mL}$ Hoagland's nutrient solution), VCL treatment showed significantly greater shoot/root length (Fig. 3A-B) and fresh weight (Fig. 3C-D). Most of the morphological growth parameters examined at 30 and $45 \mathrm{~mL}$ of watering regime exhibited higher values for VCL-treated seedling with the only exception being the root length (Fig. 3B). These results were significantly different from the controls. Vermicompost-leachate application significantly reduced all photosynthetic
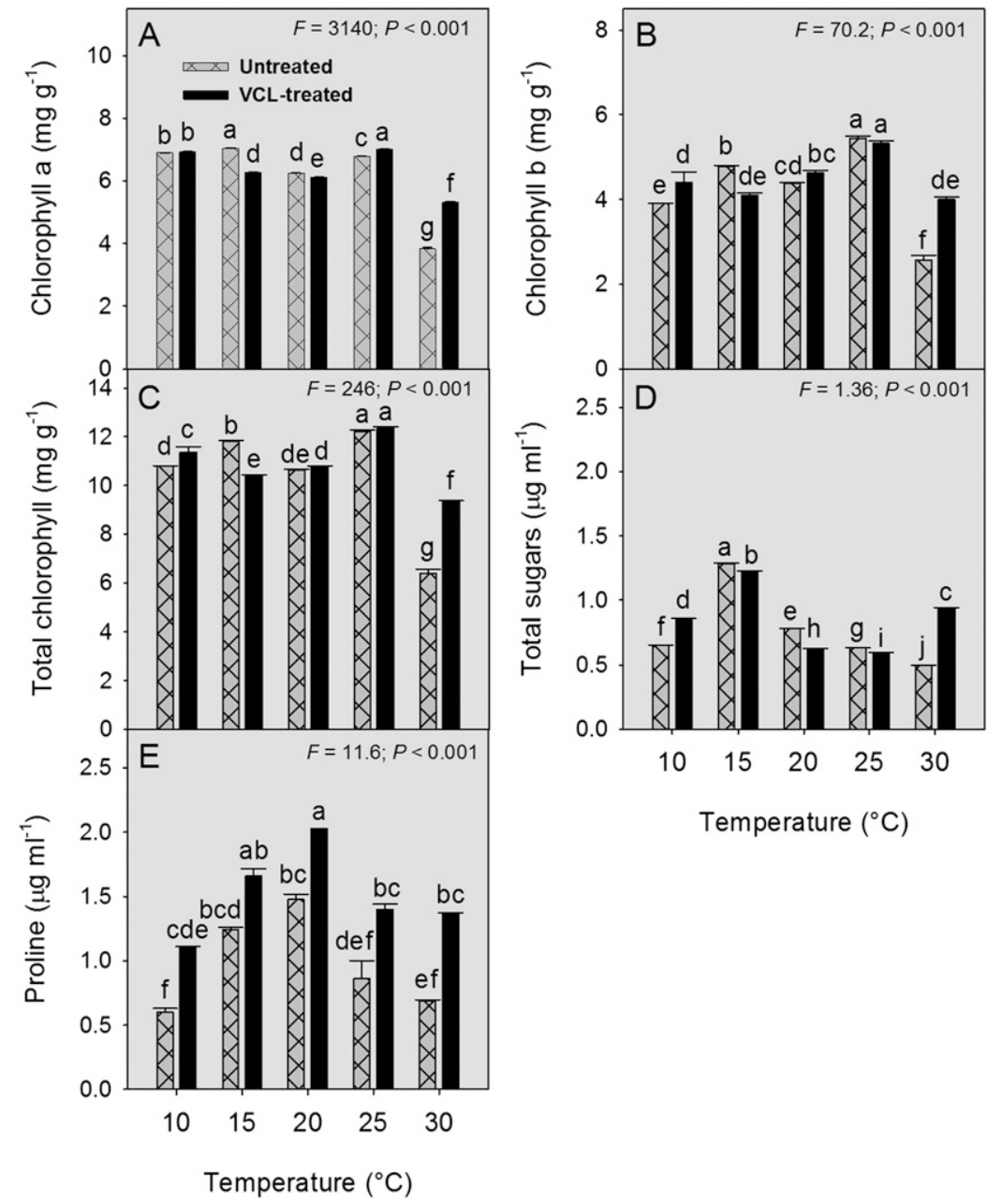

Fig. 2. (A-E) Effect of vermicompost-leachate $(1: 10 \mathrm{v} / \mathrm{v})$ on physiological parameters of tomato seedlings $(10$-week-old) grown under different temperature regimes $(n=3)$. Bars $( \pm S E)$ with different letters are significantly different according to Duncan's multiple range test $(P<0.05)$.

Table 2. Effect of vermicompost-leachate $(1: 10 \mathrm{v} / \mathrm{v})$ on morphological growth parameters of tomato seedlings $\left(10\right.$-week-old) under different watering regimes $(\mathrm{n}=5) \mathrm{.}^{\mathrm{z}}$

\begin{tabular}{lccc}
\hline Treatment & Leaf number & Stem thickness $(\mathrm{mm})$ & Plant leaf $\operatorname{area}^{\left(\mathrm{cm}^{2}\right)}$ \\
\hline Untreated & $7.8 \pm 0.13 \mathrm{~d}$ & $1.3 \pm 0.082 \mathrm{~d}$ & $13 \pm 4 \mathrm{e}$ \\
$15 \mathrm{~mL}$ water & $10.9 \pm 0.25 \mathrm{~b}$ & $1.7 \pm 0.100 \mathrm{c}$ & $22 \pm 2 \mathrm{~cd}$ \\
$30 \mathrm{~mL}$ water & $12.2 \pm 0.22 \mathrm{a}$ & $1.6 \pm 0.090 \mathrm{c}$ & $28 \pm 2 \mathrm{bc}$ \\
$45 \mathrm{~mL}$ water & & & $17 \pm 1 \mathrm{de}$ \\
VCL-treated $(1: 10 \mathrm{v} / \mathrm{v})$ & $12.2 \pm 0.40 \mathrm{a}$ & $2.4 \pm 0.100 \mathrm{~b}$ & $35 \pm 3 \mathrm{ab}$ \\
$15 \mathrm{~mL}$ water & $13 \pm 0.31 \mathrm{a}$ & $2.9 \pm 0.199 \mathrm{a}$ & $39 \pm 3 \mathrm{a}$ \\
$30 \mathrm{~mL}$ water & 49.7 & 20.15 & 12.3 \\
$45 \mathrm{~mL}$ water & $<0.001$ & $<0.001$ & $<0.001$ \\
$F$-value & & & \\
$P$ value & &
\end{tabular}

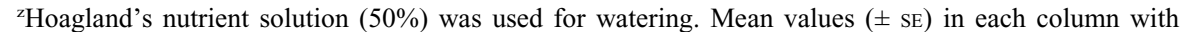
different letters are significantly different according to Duncan's multiple range test $(P<0.05)$. VCL $=$ vermicompost-leachate.

pigment contents at the $15-\mathrm{mL}$ watering regime (Fig. 4A-C). However, this trend was reversed with increasing supply of water. Both total soluble sugars and proline content of control seedlings at $15-\mathrm{mL}$ watering regime were $\approx 70 \%$ more than that of the VCL-treated tomato seedlings (Fig. 4D-E). In general, compatible solute content of treated and untreated tomato seedlings was significantly reduced with 30 and $45 \mathrm{~mL}$ water supply.

\section{Discussion}

Most of the morphological parameters of VCL-treated tomato seedlings were not only markedly enhanced at optimum temperature $\left(25^{\circ} \mathrm{C}\right)$, but under high temperature $\left(30^{\circ} \mathrm{C}\right)$ also exhibited significant improvement (Table 1; Fig. 1). At lower temperatures (10, 15, and $20^{\circ} \mathrm{C}$ ), although VCL promoted several growth parameters of a tomato seedling, this improvement did not differ significantly with 


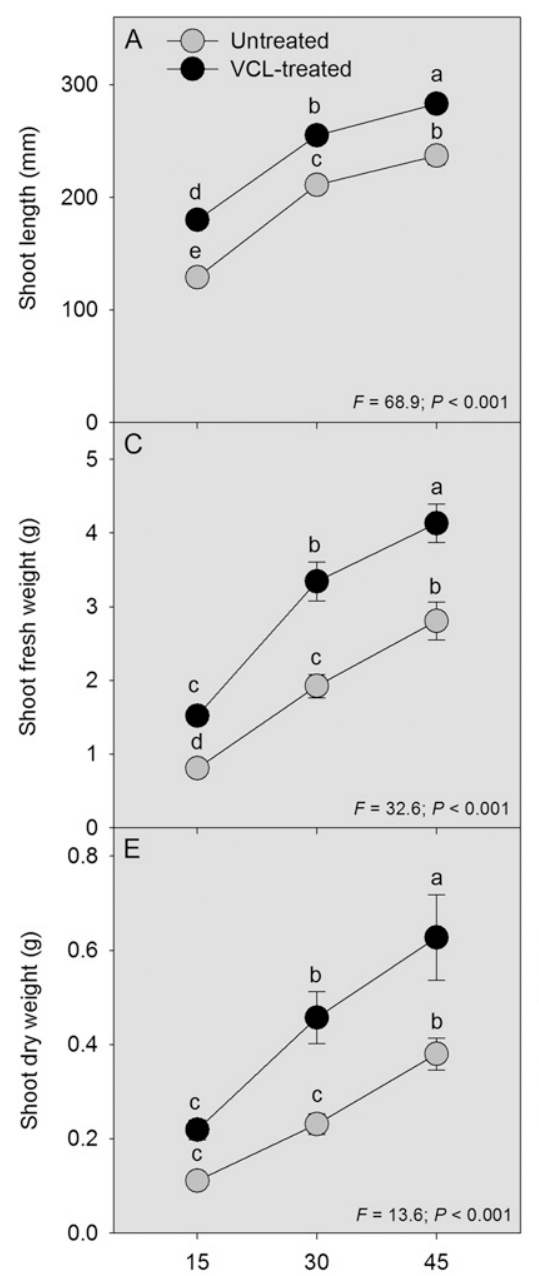

Water quantity supplied $(\mathrm{mL})$

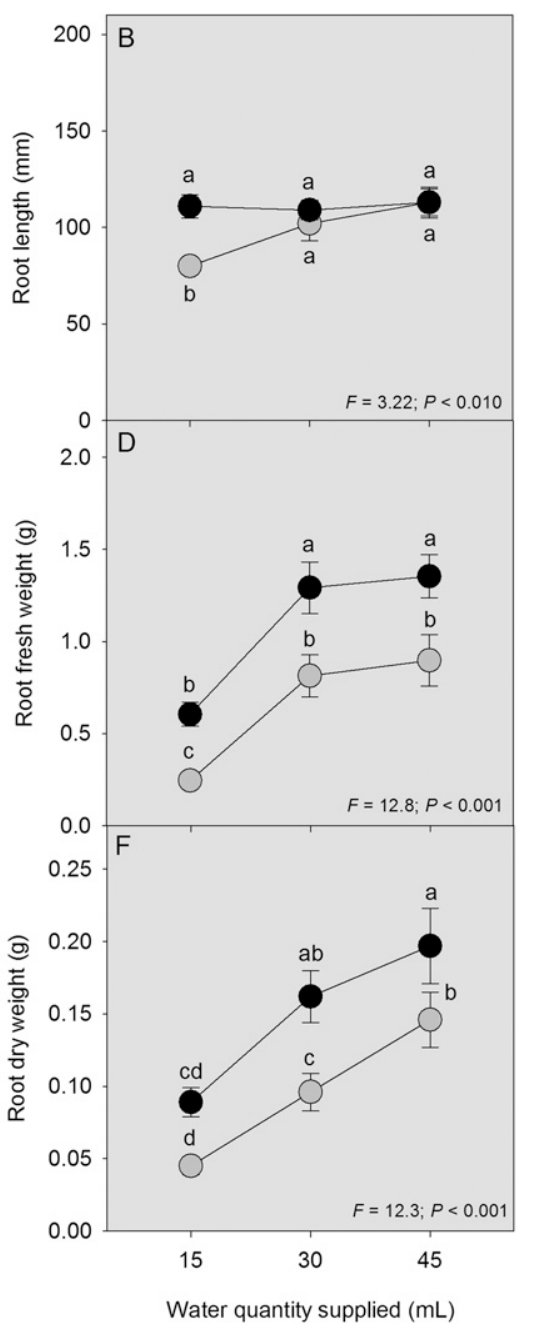

Fig. 3. (A-F) Effect of vermicompost-leachate $(1: 10 \mathrm{v} / \mathrm{v})$ on shoot and root growth parameters of tomato seedlings (10-week-old) grown under different watering regimes. Hoagland's nutrient solution $(50 \%)$ was used for watering $(\mathrm{n}=5)$. Symbols $( \pm \mathrm{SE})$ with different letters are significantly different according to Duncan's multiple range test $(P<0.05)$.

the respective controls. Van der Ploeg and Heuvelink (2005) reported that suboptimal temperatures $\left(19\right.$ to $20^{\circ} \mathrm{C}$ ) produced shortened shoots and significantly affected various developmental and growth characteristics in tomato. Transgenic maize plants were found to be more drought-tolerant as a result of increased chlorophyll content (Cramer et al., 2011). An increase in chlorophyll a, b, total chlorophyll, and total sugar content in VCL-treated tomato seedlings under high temperature stress $\left(30^{\circ} \mathrm{C}\right)$ may have induced a similar tolerance effect.

Abiotic stresses such as declining water resources and extreme temperatures can reduce overall plant growth, development, and yield. In the case of water stress, reduced water uptake at initial growth stages will hamper the ability of water distribution at later stages. If water stress precedes inhibition of photosynthesis, the plant's ability to accumulate solutes to increase water potential gradient is also hindered (Cramer et al., 2011). Under such conditions there is the added risk of reactive oxygen species causing oxidative stress. Alternatively, established plants generally accumulate compatible solutes and close their stomata to create a low water potential and prevent water loss during water stress conditions (Skirycz and Inzé, 2010). Osmotic adjustment by the accumulation of solutes is necessary to lower the risk of osmotic and oxidative were previously shown to have increased concentrations of compatible solutes such as sucrose, glucose, fructose, and proline in the fruit and leaves (Nahar and Gretzmacher, 2002). In this study, a similar growth response and osmotic adjustment in untreated water-stressed $(15 \mathrm{~mL})$ tomato seedlings was detected (Figs. 3 and 4). Photosynthetic pigments and compatible solute contents were significantly reduced in VCL-treated tomato seedlings at $15 \mathrm{~mL}$, indicating an induced tolerance mechanism resulting from the addition of VCL. Physiological parameters were reduced within the range of those found in more favorable conditions as observed for 30-mL supply of nutrient solution (Fig. 4). The significant results of the water stress experiment demonstrate the stress. Water-stressed tomato seedlings possibility of using less water resources to produce a quality crop.

Similarly, the constant supply of VCL improved various morphological characters including leaf area and shoot/root biomass, enabling VCL-treated tomato seedlings to perform better (Table 2; Fig. 3). Stem thickness of VCL-treated tomato seedlings under different temperatures $\left(10,25\right.$, and $\left.30{ }^{\circ} \mathrm{C}\right)$ and at $30-\mathrm{mL}$ watering regime was also better. This finding is in accordance with Oliva-Llaven et al. (2010), where daily foliar application of worm-bed leachate produced thicker stems in tomato plants. Stem thickness is a good indicator of plant sturdiness and also important in improving the carrying capacity of crop during fruiting.

Garcia et al. (2007) reported that the supply of optimum nitrogen can promote drought tolerance in tomato plants by reducing cell membrane damage and improving osmoregulation in the plant. León-Anzueto et al. (2011) quantified the total nitrogen content of vermicompost and worm-bed leachate to be 132 $\mathrm{mg} \cdot \mathrm{kg}^{-1}$ and $15.3 \mathrm{~g} \cdot \mathrm{L}^{-1}$, respectively. The availability of nitrogen $(2.26 \%)$, phosphorus $(0.99 \%)$, potassium $(0.64 \%)$, calcium $(2.52 \%)$, and sodium $\left(631.03 \mathrm{mg} \cdot \mathrm{kg}^{-1}\right)$ in the VCL and its addition to the Hoagland's nutrient solution may have contributed to some of the positive results observed in this study. Bacteria present in vermicompost have plant growth-promoting effects that aid in nitrogen fixation, solubilization of nutrients, and production of growth hormones (Azarmi et al., 2008). Tomati et al. (1988) reported increased root growth and biomass as well as improved nitrogen assimilation using vermicompost.

This study clearly demonstrates the growth-enhancing effects of VCL on tomato seedlings under high temperature and water stress conditions. Vermicompost-leachate exhibited better growth performance of tomato seedling under supraoptimal than at suboptimal temperatures. The significant results of the water stress experiment suggest the possibility of using less water resources to produce quality crops. Vermicompost-leachate was shown to be a suitable soil amendment alternative that can significantly improve overall crop performance under abiotic stresses. More importantly, VCL is organic and therefore can be used as an environment-friendly fertilizer supplement.

\section{Literature Cited}

Abdelmageed, A., N. Gruda, and B. Geyer. 2003. Effect of high temperature and heat shock on tomato (Lycopersicon esculentum Mill.) genotypes under controlled conditions. Conf. Intl. Agr. Res. Dev. 8-10 Oct., Göttingen, Germany. p. $1-7$.

Arthur, G.D., A.O. Aremu, M.G. Kulkarni, and J. Van Staden. 2012. Vermicompost leachate alleviates deficiency of phosphorus and potassium in tomato seedlings. HortScience 47:1304-1307.

Azarmi, R., M.T. Giglou, and R.D. Taleshmikail. 2008. Influence of vermicompost on soil chemical and physical properties in tomato ( $\mathrm{LyCO}$ persicon esculentum) field. Afr. J. Biotechnol. 7:2397-2401. 

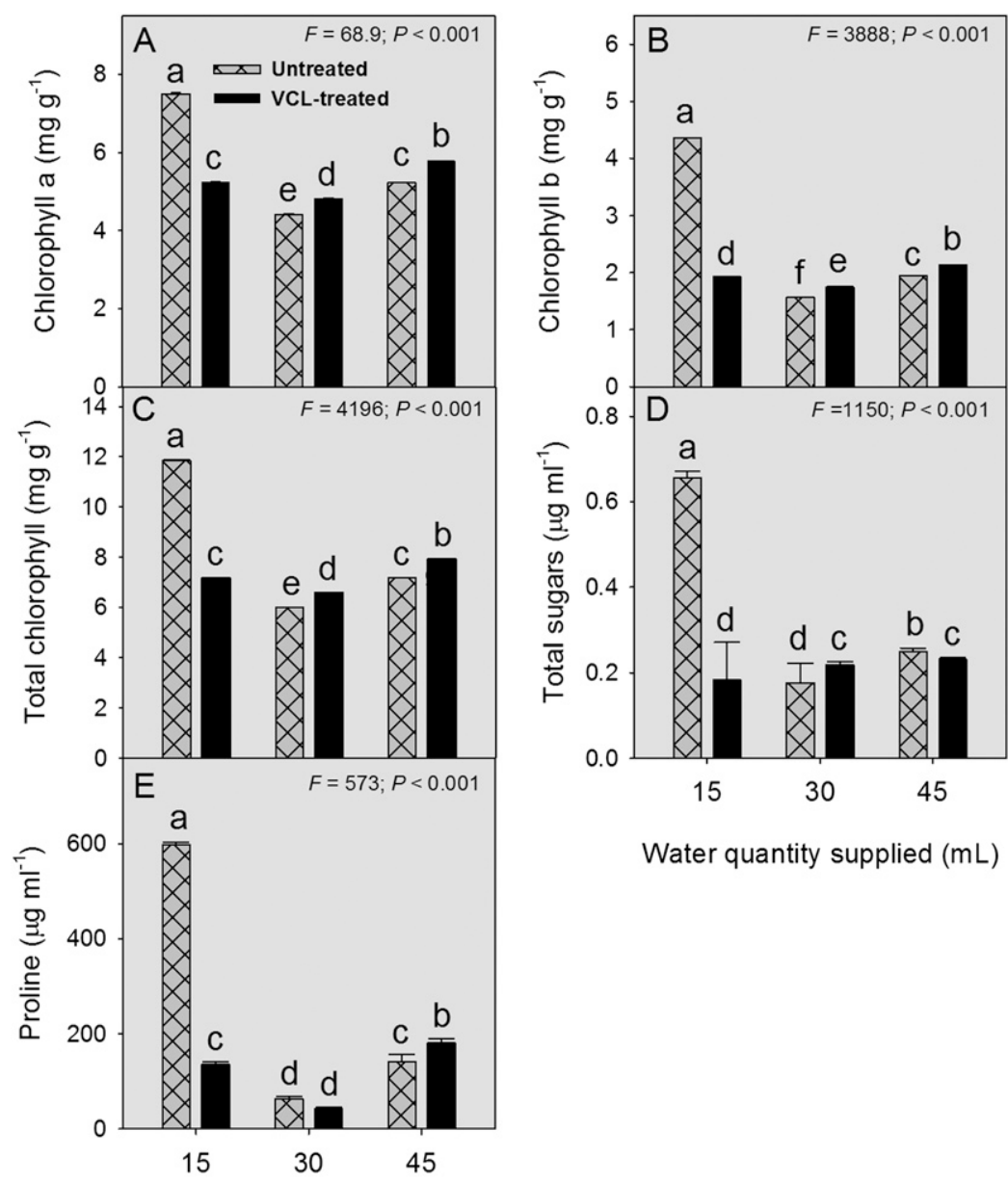

Water quantity supplied $(\mathrm{mL})$

Water quantity supplied $(\mathrm{mL})$

Fig. 4. (A-E) Effect of vermicompost-leachate $(1: 10 \mathrm{v} / \mathrm{v})$ on physiological parameters of tomato seedlings $(10$-week-old) grown under different watering regimes $(n=3)$. Hoagland's nutrient solution $(50 \%)$ was used for watering. Bars $( \pm \mathrm{SE})$ with different letters are significantly different according to Duncan's multiple range test $(P<0.05)$.

Bates, L., R. Waldren, and I. Teare. 1973. Rapid determination of free proline for water-stress studies. Plant Soil 39:205-207.

Chaoui, H.I., L.M. Zibilske, and T. Ohno. 2003. Effects of earthworm casts and compost on soil microbial activity and plant nutrient availability. Soil Biol. Biochem. 35:295-302.

Cramer, G.R., K. Urano, S. Delrot, M. Pezzotti, and K. Shinozaki. 2011. Effects of abiotic stress on plants: A systems biology perspective. BMC Plant Biol. 11:163.

Criddle, R.S., B.N. Smith, and L.D. Hansen. 1997. A respiration based description of plant growth rate responses to temperature. Planta 201:441445.

Garcia, A., L. Marcelis, F. García-Sánchez, N. Nicolas, and V. Martínez. 2007. Moderate water stress affects tomato leaf water relations in dependence on the nitrogen supply. Biol. Plant. 51:707-712.

Hoagland, D. and W. Snyder. 1933. Nutrition of strawberry plants under controlled conditions. Proc. Am. Soc. Hort. Sci. 30:288-296.

León-Anzueto, E., M. Abud-Archila, L. Dendooven, L.M.C. Ventura-Canseco, and F.A. GutiérrezMiceli. 2011. Effect of vermicompost, worm-bed leachate and arbuscular mycorrizal fungi on lemongrass [Cymbopogon citratus (DC) Stapf.] growth and composition of its essential oil. Electron. J. Biotechnol. 14:5.

Men, F. and M. Liu. 1995. Physiology of potato China Agriculture Press, Beijing, China.

Nahar, K. and R. Gretzmacher. 2002. Effect of water stress on nutrient uptake, yield and quality of tomato (Lycopersicon esculentum Mill.) under subtropical conditions. Bodenkultur 53:45-51.

Nuruddin, M.M., C.A. Madramootoo, and G.T. Dodds. 2003. Effects of water stress at different growth stages on greenhouse tomato yield and quality. HortScience 38:1389-1393.

Oliva-Llaven, M.Á., L. Rodríguez-Hernández, P. Mendoza-Nazar, B. Ruiz-Sesma, J.D Álvarez-Solís, L. Dendooven, and F.A. Gutiérrez-Miceli. 2010. Optimization of worm-bed leachate for culturing of tomato (Lycopersicon esculentum Mill) inoculated with Glomus fasciculatum and Pseudomonas fluorescens. Electron. J. Biotechnol. 13:4-5.

Rivero, R.M., J.M. Ruiz, P.C. García, L.R. LópezLefebre, E. Sánchez, and L. Romero. 2001. Resistance to cold and heat stress: Accumulation of phenolic compounds in tomato and watermelon plants. Plant Sci. 160:315-321.

Sanchez, P.A., W. Couto, and S.W. Buol. 1982 The fertility capability soil classification system: Interpretation, applicability and modification. Geoderma 27:283-309.

Sinha, R.K., S. Heart, D. Valani, and K. Chauhan. 2009. The concept of sustainable agriculture: An issue of food safety and security for people, economic prosperity for the farmers and ecological security for the nations. AmericanEurasian J. Agr. Environ. Sci. 5(S):1-4.

Skirycz, A. and D. Inzé. 2010. More from less: Plant growth under limited water. Curr. Opin. Biotechnol. 21:197-203.

Tomati, U., A. Grappelli, and E. Galli. 1988. The hormone-like effect of earthworm casts on plant growth. Biol. Fertil. Soils 5:288-294.

Van der Ploeg, A. and E. Heuvelink. 2005. Influence of sub-optimal temperature on tomato growth and yield. J. Hort. Sci. Biotechnol. 80:652-659. 